JIKAP PGSD: Jurnal Ilmiah Ilmu Kependidikan

Vol,3. No,3. Tahun 2019

e-ISSN: 2597-4440 dan p-ISSN: 2597-4424

This work is licensed under a Creative Commons Attribution

4.0 International License

\title{
Peningkatan Kemampuan Guru Dalam Pengembangan Silabus Dan RPP Melalui Pola Pembinaan Profesional Dengan Pendekatan Kooperatif
}

\author{
A Sommeng \\ Dinas Pendidikan Kabupaten Bone \\ Email: a.Sommeng@gmail.com
}

\begin{abstract}
Abstrak. Penelitian tentang peningkatan kemampuan guru dalam pengembangan silabus dan RPP melalui pola pembinaan profesional dengan pendekatan kooperatif di Daerah Binaan III SD Negeri 112 Pacciro pada tahun pelajaran 2018. Jenis penelitian ini adalah penelitian tindakan (action research) dengan 4 tahapan, yaitu perencanaan, pelaksanaan, observasi dan refleksi. Subjek penelitian sebanyak 8 guru di Daerah Binaan III SD Negeri 112 Pacciro pada tahun pelajaran 2018. Teknik pengumpulan data dilakukan dengan kegiatan observasi dan dokumentasi. Validasi data menggunakan teknik triangaluasi. Analisis data menggunakan teknik deskriptif. Hasil penelitian menunjukkan peningkatan kemampuan guru dalam pengembangan silabus dan perencanaan pelaksanaan pembelajaran meningkat yakni dari nilai rata-rata dari 49,59 dengan kriteria nilai kurang pada kondisi awal, menjadi 69,98 kriteria nilai cukup pada siklus pertama dan menjadi 89,47 kriteria nilai sangat baik pada siklus kedua. Kesimpulannya adalah pola pembinaan profesional dengan pendekatan kooperatif terbukti dapat meningkatkan kemampuan guru dalam pengembangan silabus dan RPP di Daerah Binaan III SD Negeri 112 Pacciro pada tahun pelajaran 2018.
\end{abstract}

Kata kunci: Peningkatan Kemampuan;pengembangan silabus dan RPP;pendekatan kooperatif

Abstract. Research on improving the ability of teachers in the development of syllabus and lesson plans through professional coaching patterns with a cooperative approach in the Assisted Region III of SD Negeri 112 Pacciro in 2018. This type of research is action research with 4 stages, namely planning, implementation, observation and reflection. The research subjects were 8 teachers in the Assisted Region III Elementary School 112 Pacciro in the 2018 school year. Data collection techniques were carried out with observation and documentation. Data validation uses triangaluation techniques. Data analysis uses descriptive techniques. The results showed an increase in the ability of teachers in the development of the syllabus and planning for the implementation of learning increased from an average value of 49.59 with criteria of under-grade values at the initial condition, to 69.98 criteria for sufficient grades in the first cycle and to become 89.47 criteria for very grades good in the second cycle. The conclusion is that the pattern of professional coaching with a cooperative approach is proven to be able to improve the ability of teachers in the development of syllabus and RPP in the Binaan III Regional SD Negeri 112 Pacciro in 2018. 
Keywords: Capacity building; syllabus development and learning implementation plan; cooperative approach

\section{PENDAHULUAN}

Undang-undang No. 14 tahun 2005 tentang Guru dan Dosen (UGD) semakin menegaskan komitmen pemerintah dalam peningkatan mutu, relevansi, dan daya saing di masa depan. UGD menyebutkan bahwa ke depan guru dipersyaratkan untuk memiliki kualifikasi akademik yang relevan dan menguasai kompetensi sebagai agen pembelajaran. Kompetensi sebagai agen pembelajaran yang harus dikuasai oleh guru meliputi kompetensi kepribadian, kompetensi pedagogik, kompetensi profesional, dan kompetensi sosial.

Peraturan pemerintah RI No. 19 tahun 2005 tentang Standar Nasional Pendidikan menyatakan bahwa kompetensi pedagogik sebagai agen pembalajaran pada jenjang pendidikan dasar dan menengah serta pendidikan anak usia dini. Diantara kompetensi tersebut adalah kompetensi pedagogik. Kompetensi ini meliputi tiga hal yaitu (1) Kemampuan dalam merencanakan pembelajaran, (2) Kemampuan dalam melaksanakan pembelajaran, dan (3) Kemampuan dalam mengevaluasi pembelajaran.

Kompetensi guru tersebut bersifat menyeluruh dan merupakan satu kesatuan yang satu sama lain saling berhubungan dan saling mendukung. Kompetensi pedagogik yang dimaksud di sini adalah kemampuan pemahaman tentang peserta didik secara mendalam dan penyelengaraan pembelajaran yang mendidik. Pemahaman tentang peserta didik ini meliputi pemahaman tentang psikologi perkembangan anak sedangkan pembelajaran yang mendidik meliputi kemampuan merencanakan pembelajaran, mengimplementaikan pembelajaran, menilai proses dan hasil pembelajaran, dan melaksanakan secara berkelanjutan.

Pendidikan merupakan salah satu prioritas program pembangunan di Indonesia, karena isu mengenai mutu pendidikan sampai saat ini masih bergulir. Upaya meningkatkan mutu pendidikan menjadi priotitas utama, disamping pemerataan, relevansi, efesiensi, dan efektivitas. Berbagai usaha telah dilakukan untuk meningkatkan kompetensi guru, antara lain melalui pelatihan, workshop, bimbingan teknik, dan uji sertifikasi. Namun demikian berbagai indikator peningkatan kompetensi guru belum menunjukkan peningkatan yang signifikan. Yuwono (2001:3) menyatakan bahwa usaha-usaha perbaikan pembelajaran sudah dilakukan namun belum menampakkan hasil yang memuaskan. Guru selama ini lemah dalam menyusun silabus dan rencana pelaksanaan pembelajaran (RPP) yang menjadi pedoman pada saat pembelajaran di kelas. Bahkan ada yang tidak menyusunnya sama sekali, padahal kualitas rencana pelaksanaan pembelajaran sangat menentukan hasil kegiatan belajar mengajar.

Gambaran kemampuan kompetensikompetensi tersebut akan tampak pada perencanaan pembelajaran. Perencanaan pembelajaran yang tepat tentu saja akan sangat mendukung dalam pelaksanaan pembelajaran. Untuk dapat mengetahui pelaksanaan pembelajaran tentu saja diperlukan kesungguhan dalam mengobservasi guru ketika mengajar guna mengetahui kemampuan guru dalam memberikan rangsangan pada siswa untuk bereksplorasi, melakukan kalaborasi dan guru mampu melakukan konfirmasi atas pembelajaran yang telah berlangsung oleh Pengawas Sekolah.

Pengawas Sekolah sebagai pemimpin tertinggi yang sangat berpengaruh dan menentukan kemajuan sekolah harus memiliki kemampuan administrasi, memiliki komitmen tinggi dan luwes dalam melaksanakan tugasnya. Pengawas Sekolah juga harus melakukan peningkatan profesionalisme sesuai dengan gaya kepemimpinannya, berangkat dari niat, kemauan dan kesediaan, bersifat memprakarsai dan didasari pertimbangan yang matang, lebih berorientasi kepada bawahan, demokratis, lebih terfokus pada hubungan daripada tugas serta mempertimbangkan kematangan bawahan.

Perencanaan program berfungsi untuk memberikan arah pelaksanaan pembelajaran sehingga menjadi terarah dan efisien. Salah satu bagian dari perencanaan pembelajaran yang sangat penting dibuat oleh guru sebagai pengarah pembelajaran adalah silabus dan Rencana Pelaksanaan Pembelajaran (RPP). Silabus memberikan arah tentang apa saja yang harus dicapai guna menggapai tujuan pembelajaran dan cara seperti apa yang akan digunakan. Selain itu silabus juga memuat teknik penilaian seperti apa untuk menguji sejauh mana keberhasilan pembelajaran. Rencana Pelaksanaan Pembelajaran (RPP) adalah instrument perencanaan yang lebih spesifik dari silabus. Rencana Pelaksanaan 
Pembelajaran ini dibuat untuk memandu guru dalam mengajar agar tidak melebar jauh dari tujuan pembelajaran.

Dengan melihat pentingnya penyusunan perencanaan pembelajaran ini, guru semestinya tidak mengajar tanpa adanya rencana. Namun sayang perencanaan pembelajaran yang mestinya dapat di ukur oleh kepala sekolah ini, tidak dapat diukur oleh kepala sekolah karena hanya direncanakan dalam pikiran sang guru saja. Akibatnya Pengawas Sekolah sebagai pembuat kebijakan di sekolah tidak dapat mengevaluasi kinerja guru secara akademik. Kinerja yang dapat dilihat oleh kepala sekolah hanyalah kehadiran tatap muka, tanpa mengetahui apakah kemampuan guru dalam mengelola pembelajaran sudah sesuai dengan harapan atau belum, atau sudahkah kompetensi dasar yang harus dikuasai oleh siswa terkuasai dengan benar.

Hasil pengamatan terhadap 8 guru di Daerah Binaan III SD Negeri 112 Pacciro Kecamatan Ajangale Kabupaten Bone pada tahun pelajaran 2018. didapatkan data bahwa hampir semua guru belum mampu mengembangkan silabus dan RPP sesuai dengan petunjuk teknis yang menjadi acuan. Hal tersebut dibuktikan dari hasil kegiatan awal penelitian dimana diperoleh data bahwa hanya terdapat 2 guru atau 25\% yang berada dalam kriteria penilaian cukup, dan 6 guru atau $75 \%$ dalam penilain kurang.

Oleh karena itu upaya peningkatan kompetensi terus dilakukan. Upaya ini diantaranya dengan mengadakan pembinaan profesional dengan memadukan berbagai pendekatan salah satunya adalah dengan pendekatan kooperatif yang dituangkan dalam bentuk penelitian tindakan sekolah dengan judul "Peningkatan Kemampuan Guru dalam Pengembangan Silabus dan RPP melalui Pola Pembinaan Profesional dengan Pendekatan Kooperatif di Daerah Binaan III SD Negeri 112 Pacciro Kecamatan Ajangale Kabupaten Bone pada tahun pelajaran 2018." Hal didukung oleh hasil penelitian Jauhari (2019:1) pembelajaran Kooperatif dapat meningkatkan aktifitas dan hasil pembelajaran.

\section{METODE PENELITIAN}

Lokasi pelaksanaan kegiatan penelitian tindakan sekolah ini dilaksanakan di Daerah Binaan III SD Negeri 112 Pacciro Kecamatan Ajangale Kabupaten Bone. Penelitian tindakan sekolah ini dilaksanakan pada tahun pelajaran
2018 dan dilaksanakan dalam 6 bulan dimulai dari bulan Januari 2018 sampai dengan bulan Juni 2018.

Jenis Penelitian Penelitian yang digunakan adalah Penelitian Tindakan Sekolah (PTS) dan dilaksanakan dalam 2 siklus. Metode dan rancangan penelitian PTS meliputi, yaitu: perencanaan, pelaksanaan, pengamatan, dan refleksi. Siklus PTS meliputi empat langkah yaitu: perencanaan, pelaksanaan, pengamatan dan evaluasi, serta refleksi. Masing-masing langkah dijelaskan sebagai berikut:

1. Perencanaan

Perencanaan adalah langkah awal yang dilakukan peneliti saat akan memulai tindakannya. Agar perencanaan mudah dipahami oleh peneliti yang akan melakukan tindakan, maka peneliti membuat rencana tindakan.

2. Pelaksanaan

Pelaksanaan adalah penerapan dari perencanaan. Hal-hal yang harus diperhatikan oleh peneliti

3. Pengamatan

Pengamatan adalah pencermatan terhadap pelaksanaan tindakan. Hal-hal yang diamati adalah proses tindakan yang berlangsung selama tahap pelaksanaanPTS. Pengamatan menggunakan instrumen yang berisi indikatorindikator proses tindakan.

4. Evaluasi

Evaluasi adalah proses penetapan hasil pelaksanaan tindakan berdasarkan indikatorindikator tujuan PTS yang telah ditetapkan. Hasil evaluasi digunakan sebagai dasar untuk melakukan refleksi.

5. Refleksi

Bentuk tindakan dalam penelitian ini adalah pola pembinaan profesional dengan pendekatan kooperatif sebagai upaya meningkatkan kemampuan guru dalam pengembangan silabus dan RPP.

Subjek penelitian tindakan sekolah ini sebanyak 8 guru dengan penjelasan di Daerah Binaan III SD Negeri 112 Pacciro Kecamatan Ajangale Kabupaten Bone pada tahun pelajaran 2018.

Teknik pengumpulan data dalam penelitian ini menggunakan beberapa metode diantaranya :

a. Observasi

Observasi adalah pengamatan dan pencatatan yang sistematis terhadap gejalagejala yang diteliti (Usman dan Akbar, 1995 : 54). 


\section{b. Dokumentasi}

Teknik pengumpulan data dengan dokumentasi ialah pengambilan data yang diperoleh melalui dokumen-dokumen (Usman dan Akbar, 1995 : 75) Dokumentasi adalah suatu metode pencarian data mengenai hal-hal atau variabel berupa catatan transkip, buku, surat kabar, majalan dan lainnya. Aspek-aspek untuk menambah kelengkapan data dalam dokumentasi meliputi catatan-catatan, foto-foto (Arikunto, 1982: 187).

Teknik dokumentasi untuk mendapatkan latar belakang yang luas, tentang pokok-pokok penelitian, dan dapat dijadikan triangulasi untuk mengecek kesesuaian data (Nasution,1996). Dokumen lama dapat digunakan dalam penelitian sebagai sumber data, dan dimanfaatkan untuk menguji, menafsirkan, bahkan untuk meramalkan (Moleong, 1989).

Pengumpulan data pada penelitian ini menggunakan lembar observasi untuk memberikan gambaran peningkatan kompetensi guru dalam pengembangan silabus dan RPP. Selain itu lembar observasi ini bertujuan untuk mengetahui kekurangan-kekurangan yang harus diperbaiki atau kelebihan-kelebihan yang harus dipertahankan dan ditingkatkan pada kegiatan berikutnya.

Dalam penelitian ini validasi data dilakukan dengan teknik triangulasi. Triangulasi dilakukan dengan maksud untuk mengecek kebenaran data yang diperoleh dan membandingkannya dengan data yang diperoleh dari sumber lain. Tujuan triangulasi ialah mencek kebenaran data tertentu dengan membandingkannya dengan data-data yang diperoleh dari sumber lain. Sebagaimana yang diungkapkan oleh Moleong (2008:330) bahwa: "Triangulasi adalah teknik pemeriksaan keabsahan data yang memanfaatkan sesuatu yang lain diluar data itu untuk keperluan pengecekan atau sebagai pembanding terhadap data itu".

Analisis data yang digunakan dalam penelitian ini adalah statistik deskriptif. Menurut Sugiyono (2006) statistik deskriptif digunakan untuk menganalisis data dengan cara mendeskripsikan atau menggambarkan data yang telah terkumpul sebagaimana adanya tanpa membuat kesimpulan yang belaku secara umum atau generalisasi. Sehingga dalam penelitian tindakan dengan menggunakan statistik deskriptif tidak ada uji signifikansi, tidak ada taraf kesalahan, karena peneliti tidak bermaksud membuat generalisasi.
Untuk menentukan berhasil dan tidaknya dalam penelitian tindakan sekolah. Peneliti merumuskan indikator keberhasilan sebagai berikut :

1. Adanya peningkatan nilai rata-rata penilaian hasil observasi yang dicapai oleh peserta dalam penguasaan tentang silabus dan rencana pelaksanaan pembelajaran, ditandai dengan nilai ketuntasan lebih dari 70 atau minimal mendapat kriteria nilai baik.

2. Secara klasikal minimal $85 \%$ guru meningkat kompetensinya dalam pengembangan silabus dan rencana pelaksanaan pembelajaran.

\section{HASIL DAN PEMBAHASAN}

1. Data Kondisi Awal

Perencanaan program berfungsi untuk memberikan arah pelaksanaan pembelajaran sehingga menjadi terarah dan efisien. Salah satu bagian dari perencanaan pembelajaran yang sangat penting dibuat oleh guru sebagai pengarah pembelajaran adalah silabus dan Rencana Pelaksanaan Pembelajaran (RPP). Silabus memberikan arah tentang apa saja yang harus dicapai guna menggapai tujuan pembelajaran dan cara seperti apa yang akan digunakan. Selain itu silabus juga memuat teknik penilaian seperti apa untuk menguji sejauh mana keberhasilan pembelajaran. Rencana Pelaksanaan Pembelajaran (RPP) adalah instrument perencanaan yang lebih spesifik dari silabus.

Hasil pengamatan terhadap 8 guru di Daerah Binaan III SD Negeri 112 Pacciro Kecamatan Ajangale Kabupaten Bone pada tahun pelajaran 2018. didapatkan data bahwa hampir semua guru belum mampu mengembangkan silabus dan RPP sesuai dengan petunjuk teknis yang menjadi acuan. Hal tersebut dibuktikan dari hasil kegiatan awal penelitian dimana diperoleh data bahwa hanya terdapat 2 guru atau 25\% yang berada dalam kriteria penilaian cukup, dan 6 guru atau $75 \%$ dalam penilain kurang.Oleh karena itu upaya peningkatan kompetensi terus dilakukan. Upaya ini diantaranya dengan mengadakan pembinaan profesional dengan memadukan berbagai pendekatan salah satunya adalah dengan pendekatan kooperatif.

Hasil penilaian pada kegiatan observasi awal terhadap kompetensi guru terhadap pengembangan silabus dan RPP pada kondisi awal sebagaimana dijelaskan pada tabel di bawah ini. 
Tabel 1: Rekapitulasi Hasil Observasi Kemampuan Guru dalam Pengembangan Silabus dan RPP pada Kondisi Awal

\begin{tabular}{cccccc}
\hline No & Nama Guru & Skor & Kriteria Nilai & Tuntas & Belum \\
\hline $\mathbf{1}$ & 55,92 & $\mathrm{C}$ & - & $\mathrm{B}$ \\
\hline $\mathbf{2}$ & 53,29 & $\mathrm{~K}$ & - & $\mathrm{B}$ \\
\hline $\mathbf{3}$ & 42,76 & $\mathrm{~K}$ & - & $\mathrm{B}$ \\
\hline $\mathbf{4}$ & 44,08 & $\mathrm{~K}$ & - & $\mathrm{B}$ \\
\hline $\mathbf{5}$ & 55,26 & $\mathrm{C}$ & - & $\mathrm{B}$ \\
\hline $\mathbf{6}$ & 53,95 & $\mathrm{~K}$ & - & $\mathrm{B}$ \\
\hline $\mathbf{7}$ & & 44,74 & $\mathrm{~K}$ & - & $\mathrm{B}$ \\
\hline $\mathbf{8}$ & & 46,71 & $\mathrm{~K}$ & - & $\mathrm{B}$ \\
\hline & Rata-Rata & 49,59 & $\mathrm{~K}$ & 0 & 8 \\
\hline & Persentase & - & - & 0,00 & 100,00
\end{tabular}

Sumber: Hasil Angket Penelitian

Dari penjelasan tabel di atas, peningkatan kemampuan guru dalam pengembangan silabus dan RPP sebagaimana dijelaskan pada tabel di bawah ini.

Tabel 2: Rekapitulasi Peningkatan Kemampuan Guru dalam Pengembangan Silabus dan RPP pada Kondisi Awal

\begin{tabular}{ccccc}
\hline No & $\begin{array}{c}\text { Kriteria } \\
\text { Nilai }\end{array}$ & Jumlah & Persentase & Ket \\
\hline 1 & $\begin{array}{c}\text { Baik } \\
\text { Sekali }\end{array}$ & 0 & 0 \\
\hline 2 & Baik & 0 & 0 \\
\hline 3 & Cukup & 2 & 25 \\
\hline 4 & Kurang & 6 & 75 \\
\hline \multicolumn{4}{l}{ Dari penjelasan pada tabel di atas, maka }
\end{tabular}
dapat dijelaskan bahwa semua guru dinyatakan kompetensi dalam pengembangan silabus dan RPP masih rendah. hal tersebut dibuktikan dengan hasil penilaian yang dilakukan menunjukkan hasil yang cukup mengecawakan karena hanya berada pada kisaran nilai kurang dan cukup, dimana 2 guru atau $25 \%$ berada pada kriteria cukup, dan sisanya pada kriteria kurang sebanyak 6 guru atau $75 \%$ dengan nilai rata-rata sebesar 49,59 dalam kriteria kurang.

2. Data Hasil Penelitian Siklus 1

a. Perencanaan

Untuk melaksanakan siklus 1 didahului dengan menyusun materi tentang silabus dan rencana pelaksanaan pembelajaran (RPP), Selanjutnya materi pengembangan rencana pelaksanaan pembelajaran (RPP) meliputi pengertian rencana pelaksanaan pembelajaran (RPP), komponen RPP, prinsip-prinsip penyusunan RPP, dan langkah-langkah penyusunan RPP, kemudian membentuk kelompok menjadi 2 dengan anggota setiap kelompok 4 orang.

b. Tindakan

Kegiatan yang dilakukan pada pelaksanaan tindakan penelitian tindakan sekolah pada siklus pertama diantaranya dapat dijelaskan secara ringkas di bawah ini.

1. Peneliti melakukan apersepsi

2. Peneliti menyampaikan tujuan yang akan dicapai

3. Mempresentasikan materi tentang silabus dan rencana pelaksanaan pembelajaran

4. Peserta bekerja secara kelompok

5. Peserta berdiskusi untuk menyusun silabus dan RPP

6. Peserta pada tiap kelompok menyajikan hasil kerja kelompok

Hasil penilaian pada kegiatan siklus pertama terhadap kompetensi guru terhadap pengembangan silabus dan RPP pada siklus pertama sebagaimana dijelaskan pada tabel di bawah ini.

Tabel 3: Rekapitulasi Hasil Observasi Kemampuan Gurudalam Pengembangan Silabus dan RPP pada Siklus Pertama

\begin{tabular}{cccccc}
\hline No & Nama Guru & Skor & Kriteria Nilai & Tuntas & Belum \\
\hline 1 & 73,68 & B & T & - \\
\hline 2 & 65,79 & C & - & B \\
\hline 3 & 70,39 & B & T & -
\end{tabular}


JIKAP PGSD: Jurnal Ilmiah Ilmu Kependidikan

\begin{tabular}{|c|c|c|c|c|}
\hline 4 & 65,79 & $\mathrm{C}$ & - & B \\
\hline 5 & 71,71 & B & $\mathrm{T}$ & - \\
\hline 6 & 73,68 & B & $\mathrm{T}$ & - \\
\hline 7 & 69,08 & $\mathrm{C}$ & - & B \\
\hline 8 & 69,74 & $\mathrm{C}$ & - & B \\
\hline Rata-Rata & 69,98 & $\mathrm{C}$ & 4 & 4 \\
\hline Persentase & - & - & 50,00 & 50,00 \\
\hline
\end{tabular}

Dari penjelasan tabel di atas, peningkatan kemampuan guru dalam pengembangan silabus dan RPP sebagaimana dijelaskan pada tabel di bawah ini

Tabel 4: Rekapitulasi Peningkatan Kemampuan Gurudalam Pengembangan Silabus dan RPP pada Siklus Pertama

No Kriteria Jumlah Persentase Ket
Nilai

\begin{tabular}{cccc}
\hline 1 & Baik Sekali & 0 & 0 \\
\hline 2 & Baik & 4 & 50 \\
\hline 3 & Cukup & 4 & 50 \\
\hline 4 & Kurang & 0 & 0 \\
\hline
\end{tabular}

Dari penjelasan pada tabel di atas, maka dapat dijelaskan bahwa 4 guru atau 50\% dinyatakan kompetensi dalam pengembangan silabus dan RPP telah meningkat, hal tersebut dibuktikan dengan hasil penilaian yang dilakukan menunjukkan hasil yang cukup baik, sementara sisanya sebanyak 3 orang guru $50 \%$ masih berada dalam kisaran nilai di bawah indikator keberhasilan. Secara klasikalpun belum memenuhi indikator keberhasilan karena baru memperoleh nilai 69,98 dan dalam kriteria cukup.

c. Pengamatan

Pengamatan yang dilakukan oleh observer selama kegiatan berlangsung menunjukkan hasil sebagai berikut: Hasil pengamatan penelitian dari teman sejawat kepada pembina pada siklus 1, Hasil pengamatan terhadap kelompok

\section{d. Refleksi}

Setelah dilakukan pengamatan pada siklus 1 maka diadakan refleksi. Hasil proses refleksi masih banyak yang harus diperbaiki selama siklus satu seperti perencanaan kegiatan, pembagian kelompok, penjelasan materi dan peserta belum aktif dalam kegiatan.

3. Hasil Penelitian Siklus 2

a. Perencanaan

Untuk melaksanakan siklus 2 didahului dengan menyusun materi tentang silabus dan rencana pelaksanaan pembelajaran (RPP). Kemudian membentuk kelompok menjadi 4 dengan anggota setiap kelompok 2 orang sedangkan kriteria yang digunakan dalam pembentukan kelompok berdasarkan pangkat dan golongan ruang peserta pembinaan, dan menyusun lembar observasi.

b. Tindakan

Kegiatan yang dilakukan pada pelaksanaan tindakan penelitian tindakan sekolah pada siklus kedua dilandaskan pada hasil refleksi pada siklus pertama diantaranya dapat dijelaskan secara ringkas di bawah ini.

1) Peneliti melakukan apersepsi pada awal materi kegiatan.

2) Peneliti menyampaikan tujuan yang akan dicapai

3) semangat dalam mengikuti kegiatan pembinaan profesional pengawas sekolah

4) Mempresentasikan materi tentang silabus dan rencana pelaksanaan pembelajaran sebagaimana pada siklus pertama, para guru diminta memperhatikan.

5) Peserta bekerja secara kelompok dalam mengembangkan silabus dan rencana pelaksanaan pembelajaran

6) Peserta pada tiap kelompok menyajikan hasil kerja.

7) Kegiatan selanjutnya adalah melakukan penilaian terhadap komponen-komponen pengembangan silabus dan RPP

pertama terhadap kompetensi guru terhadap pengembangan silabus dan RPP pada siklus pertama sebagaimana dijelaskan pada tabel di bawah ini. 
Tabel 5: Rekapitulasi Hasil Observasi Kemampuan Guru Terhadap Pengembangan Silabus dan RPP pada Siklus Kedua

\begin{tabular}{|c|c|c|c|c|c|}
\hline No & Nama Guru & Skor & Kriteria Nilai & Tuntas & Belum \\
\hline 1 & & 94,08 & BS & $\mathrm{T}$ & - \\
\hline 2 & & 85,53 & $\mathrm{~B}$ & $\mathrm{~T}$ & - \\
\hline 3 & & 92,76 & $\mathrm{BS}$ & $\mathrm{T}$ & - \\
\hline 4 & & 84,87 & $\mathrm{~B}$ & $\mathrm{~T}$ & - \\
\hline 5 & & 90,13 & BS & $\mathrm{T}$ & - \\
\hline 6 & & 91,45 & BS & $\mathrm{T}$ & - \\
\hline 7 & & 84,87 & B & $\mathrm{T}$ & - \\
\hline 8 & & 92,11 & BS & $\mathrm{T}$ & - \\
\hline & Rata-Rata & 89,47 & BS & 8 & 0 \\
\hline & Persentase & - & - & 100,00 & 0,00 \\
\hline
\end{tabular}

Dari penjelasan tabel di atas, peningkatan kemampuan guru dalam pengembangan silabus dan RPP sebagaimana dijelaskan pada tabel di bawah ini.

Tabel 6: Rekapitulasi Peningkatan Kemampuan Guru dalam Pengembangan Silabus dan RPP pada Siklus Kedua

\begin{tabular}{ccccc}
\hline No & $\begin{array}{c}\text { Kriteria } \\
\text { Nilai }\end{array}$ & Jumlah & Persentase & Ket \\
\hline 1 & $\begin{array}{c}\text { Baik } \\
\text { Sekali }\end{array}$ & 5 & 62,50 & \\
\hline 2 & Baik & 3 & 37,50 & \\
\hline 3 & Cukup & 0 & 0 \\
\hline 4 & Kurang & 0 & 0 \\
\hline
\end{tabular}

Dari penjelasan pada tabel di atas, maka dapat dijelaskan bahwa semua orang guru atau $100 \%$ dinyatakan kompetensi dalam pengembangan silabus dan RPP telah meningkat, hal tersebut dibuktikan dengan hasil penilaian yang dilakukan menunjukkan hasil yang sangatbaik.

c. Pengamatan

1) Hasil pengamatan penelitian dari teman sejawat kepada pembina pada siklus 2 ditemukan hal-hal sebagai berikut :

a) pembentukan kelompok terencana dengan baik berdasarkan pangkat, golongan ruang dan kesetaraan jender

b) peneliti menjelaskan dengan baik cara-cara bekerja dalam kelompok.

c) peneliti dalam memberikan dampingan selama melakukan pembinaan merata.

d) peneliti memberikan motivasi pada peserta untuk dapat aktif dalam kegiatan pembinaan.

2) Hasil pengamatan terhadap perserta ada beberapa hal yang ditemukan diantaranya :

a) semua peserta sangat baik dalam memperhatikan materi pembinaan, b) peserta sudah dapat bekerja sama dengan kelompoknya,

c) tidak ada egoisme peserta

d) peserta sudah memahami dan mengusai materi pengembangan silabus dan rencana pelaksanaan pembelajaran.

3) Hasil pengamatan terhadap kelompok diperoleh temuan sebagai berikut :

a) peserta berpartisipasi aktif pada kegiatan kelompoknya.

b) semua peserta sudah mengerjakan tugas dalam kelompoknya,

c) komunikasi multi arah.

d) peserta aktif mengerjakan tugas dalam kelompok. Hal ini dapat dilihat kelompok sering mengajukan pertanyaan dan sering menyampaikan saran dan pendapat sehingga tercipta dialog yang interaktif sesama anggota kelompok dalam mengerjakan tugas-tugas yang diberikan.

d. Refleksi

Setelah dilakukan pengamatan pada siklus 2 maka diadakan refleksi pada semua kegiatan yang telah dilakukan. Hasil proses refleksi adalah sebagai berikut

1) presensi dilakukan pada awal sebelum kegiatan dimulai.

2) apersepsi sudah baik dengan menyampaikan materi prasyarat sehingga peserta sudah siap mempelajari materi yang akan diberikan oleh pembina

3) pembentukan kelompok sudah terencana dengan baik, karena menggunakan kriteria pangkat dan golongan tanpa memandang jenis kelamin dan latar belakang pendidikan,

4) peneliti merencankan kegiatan pembinaan dengan baik dengan menggunakan media LCD sehingga mempermudah peserta untuk memahami informasi yang diberikan. 
5) peneliti sangat jelas dalam menjelaskan cara-cara bekerja kelompok yaitu yang mampu membantu yang kurang mampu.

6) peneliti dalam memberikan bimbingan sudah merata, sehingga semua kelompok mendapatkan dampingan yang sama.

7) semua peserta pembinaan sudah berpartisipasi pada kegiatan kelompoknya dalam bentuk diskusi.

8) tugas kelompok tidak didominasi oleh satu atau dua anak saja sebab semua sudah aktif memberikan masukkan dalam berdiskusi kelompok.

9) pada saat pelaksanaan tes akhir peneliti mencermati tempat duduk peserta sehingga tidak ada peserta dalam satu kelompok duduk berdampingan.

10) peserta sudah baik dalam mengerjakan tugas yang diberikan oleh penelit, ini menunjukkan peneliti sudah memberi penekanan pada bagian yang penting dan harus dicermati peserta.

11) semua peserta aktif dalam kerja sama kelompok.

Untuk lebih memperjelas hasil analisis terhadap peningkatan kompetensi guru dalam pengembangan silabus dan RPP setelah dilaksanakan kegiatan penelitian tindakan kelas dengan kegiatan pembinaan profesional oleh pengawas sekolah melalui pendekatan kooperatif dalam 2 siklus sebagaimana tabel di bawah ini.

Tabel 7: Rekapitulasi Hasil Observasi Kemampuan Guru Terhadap Pengembangan Silabus dan RPP pada Kondisi Awal, Siklus I dan Siklus II

\begin{tabular}{cccccc}
\hline No & Siklus & Skor Rata-Rata Tiap Siklus & $\begin{array}{c}\text { Kriteria } \\
\text { Nilai }\end{array}$ & Tuntas & Belum \\
\hline 1 & Awal & 49,59 & K & - & B \\
\hline 2 & Satu & 69,98 & C & - & B \\
\hline 3 & Dua & 89,47 & BS & T & - \\
\hline
\end{tabular}

Dari deskripsi data hasil penelitian sebagaimana dijelaskan di atas maka dapat disimpulkan bahwa telah terjadi peningkatan kompetensi guru dalam pengembangan silabus dan RPP pada seluruh guru kelas di Daerah Binaan III SD Negeri 112 Pacciro Kecamatan Ajangale Kabupaten Bone Peningkatan kompetensi guru dalam pengembangan silabus dan RPP pada seluruh guru kelas di Daerah Binaan III SD Negeri 112 Pacciro Kecamatan Ajangale Kabupaten Bone tersebut menunjukkan pendekatan yang dilakukan oleh peneliti dengan menerapkan pembinaan profesional dengan pendekatan kooperatif sudah tepat.

Pembinaan yang dilakukan oleh pengawas sekolah bertujuan memberikan bantuan kepada guru agar dapat memperbaiki kekurangan atau kelemahan dalam proses pembelajaran serta dapat mengembangkan kemampuan yang dimilikinya secara individual maupun kelompok dalam upaya meningkatkan mutu pembelajaran. Kegiatan dengan pola pembinaan profesional dengan pendekatan kooperatif bukanlah yang semata-mata untuk menilai kegiatan pembelajaran yang dilaksanakan oleh guru. Penilaian yang dilaksanakan baik menggunakan instrumen maupun obsevasi kelas agar dianalisis terlebih dahulu permasalahannya, kemudian digunakan sebagai bahan tindak lanjut untuk membina dan membimbing guru dalam rangka meningkatkan kualitas pembelajaran, sehingga diperoleh hasil belajar peserta didik yang maksimal.

Apabila kegiatan dengan pola pembinaan profesional dengan pendekatan kooperatif ini sudah dirasakan manfaatnya dari guru maka kegiatan ini tidak akan menjadi beban, baik bagi pengawas sekolah maupun gurutetapi sudah menjadi suatu kebutuhan untuk memperbaiki situasi belajar dan mengajar di sekolah. Oleh karena itu, bukan suatu hal yang mudah untuk mencapai tujuan pembinaan, tentu diperlukan perencanaan atau program yang objektif dan berkesinambungan. Namun tidak cukup hanya memiliki program yang baik, tetapi suatu program yang baik itu harus dapat dilaksanakan dan ditindaklanjuti secara baik pula.

Banyak pengawas sekolah sudah menyusun program, tetapi tidak dapat dilaksanakan. Untuk apa menyusun program kalau hanya melengkapi dokumen saja. Konsep pengawas sekolah sebagai supervisor harus menunjukkan adanya perbaikan dalam pembelajaran pada sekolah yang dipimpinnya akan tampak setelah dilakukan sentuhan supervisor berupa bantuan untuk mengatasi kesulitan guru dalam mengajar. Untuk itulah pengawas sekolah perlu memahami program dan strategi pengajaran, sehingga ia mampu memberi 
bantuan kepada guru yang mengalami kesulitan misalnya dalam menyusun program dan strategi pengajarannya masing-masing. Bantuan yang diberikan oleh pengawas sekolah kepada guru berupa bantuan dukungan fasilitas, bahan-bahan ajar yang diperlukan, penguatan terhadap penguasaan materi dan strategi pengajaran, pelatihan-pelatihan serta bantuan lain yang akan meningkatkan efektivitas program pengajaran dan implementasi program dalam aktivitas belajar di kelas.

Secara rutin dan terjadwalpengawas sekolah melaksanakan kegiatan supervisi kepada guru-guru dengan harapan agar guru mampu memperbaiki proses pembelajaran yang dilaksanakan. Dalam prosesnya, pengawas sekolah memantau secara langsung ketika guru sedang mengajar. Guru mendesain kegiatan pembelajaran dalam bentuk rencana pembelajaran kemudian pengawas sekolah mengamati proses pembelajaran yang dilakukan guru.

Sebelum melaksanakan pembinaan dengan pola pembinaan profesional dengan pendekatan kooperatif terhadap guru, sebaiknya kepala sekolah melakukan langkah-langkah (1) menyusun program pembinaan, dalam menyusun program pembinaan harus secara sistematis dan berkesinambungan, serta melibatkan guru, dengan tujuan guru mengetahui dan memahami tujuan dilaksanakan supervisi, bukan untuk menilai dan mencari kesalahan pada guru. Tetapi untuk membantu dan memperbaiki kekurangan yang ada pada guru dalam proses pembelajaran di sekolah. Dengan dilibatkannya guru dalam menyusun program pembinaan berarti mereka turut bertanggung jawab atas keterlaksanaannya, mensosialisasikan program pembinaan, setelah program pembinaan disusun oleh pengawas sekolah, sebaiknya disosialisasikan kepada guruguru atau tenaga kependidikan lainnya dengan memberikan pengertian dan tujuan supervisi, jadwal pembinaan, dan instrumen pembinaan yang akan digunakan. Bila perlu diberikan jadwal pembinaan dan instrumen pembinaan dengan harapan guru-guru sudah mengetahui dan mempelajarinya sejak dini, akhirnya tidak terjadi kesalahpahaman antara pengawas sekolah dan guru dalam pelaksanaan pembinaan di sekolah. (3) melaksanakan pembinaan akademik, sebelum melaksanakan pembinaan terhadap guru maka seorang supervisor harus memahami terlebih dahulu prinsip-prinsip, tujuan, teknikteknik dan pendekatan pembinaan. Hal ini penting agar dapat melaksanakan pembinaan secara baik dan menyenangkan, sehingga keharmonisan hubungan dan antara pengawas sekolah dan guru akan terjalin secara kekeluargaan, dan (4) tindak lanjut hasil pembinaan, kegiatan akhir setelah melaksanakan pembinaan terhadap guru, seorang supervisor diharapkan menganalisis hasil pembinaan akademik yang telah dilakukan kepada guru dan memberikan umpan balik atau tindak lanjut berupa pembinaan, penguatan atau penghargaan (reward) dan saran-saran untuk perbaikan dalam proses kegiatan belajar mengajar di sekolah.

Kegiatan tindak lanjut merupakan
lanjutan dari kegiatan pelaksanaan pembinaan yang telah dilakukan. Untuk itu instrumen penilaian dan catatan tentang kelebihan dan kekurangan guru perlu dicatat atau direkam secara objektif oleh pengawas sekolah. Manfaatnya dari hasil penilaian dan catatan-catatan itu, nantinya dapat digunakan untuk mengadakan pembinaan baik secara individu maupun bersama sama di sekolah binaan. Pengawas sekolah harus melakukan tindak lanjut hasil pembinaan akademik dengan cara-cara : (a) meninjau kembali (review) rangkuman hasil pembinaan, (b) melakukan pembinaan terhadap guru baik secara individual maupun kelompok. Langkah-langkah pembinaan kemampuan guru melalui pembinaan akademik yaitu menciptakan hubungan yang harmonis, analisis kebutuhan guru, mengembangkan strategi dan media pembelajaran, menilai kemampuan guru, dan merevisi program pembinaan.

Hasil pembinaan itu perlu ditindak lanjuti agar memberikan dampak yang nyata untuk meningkatkan profesionalisme guru penjaskes. Selain itu, perlu melakukan cara-cara dalam menindaklanjuti pembinaan akademik sehingga menghasilkan dampak nyata yang diharapkan dapat dirasakan masyarakat atau stakeholders. Tujuan kegiatan tindak lanjut agar guru penjaskes menyadari kelemahan atau kekurangannya dalam proses pembelajaran, sehingga para guru berusaha memperbaikinya melalui pembinaan atau kegiatan keprofesian seperti pelatihan, seminar, kegiatan MGMP dan lain-lainnya.

Melihat analisis data hasil penelitian tentang peningkatan kemampuan guru di Daerah Binaan III SD Negeri 112 Pacciro dalam pengembangan silabus dan RPP maka dapat disimpulkan bahwa penerapan program pembinaan dengan pola pembinaan profesional 
dengan pendekatan kooperatifyang dilakukan secara berkelompok dan individual terbukti dapat meningkatkan kemampuan guru di Daerah Binaan III SD Negeri 112 Pacciro Kecamatan Ajangale Kabupaten Bone pada tahun pelajaran 2018. dalam pengembangan silabus dan RPP.

\section{SIMPULAN DAN SARAN}

Hasil analisis data yang diperoleh dari hasil pengamatan terhadap peserta pembinaan dan kelompok telah menunjukkan bahwa kualifikasi pelaksanaan pembinaan profesional dengan pendekatan kooperatif terhadap guruguru. Dari hasil analisis tersebut, maka peneliti dapat menyimpulkan sebagai berikut :

1. Aktivitas peserta dalam pembinaan profesional guru di di Daerah Binaan III SD Negeri 112 Pacciro Kecamatan Ajangale Kabupaten Bone pada tahun pelajaran 2018 juga meningkat

2. Kompetensi guru dalam pengembangan silabus dan perencanaan pelaksanaan pembelajaran meningkat yakni dari nilai ratarata dari 49,59 dengan kriteria nilai kurang pada kondisi awal, menjadi 69,98 kriteria nilai cukup pada siklus pertama dan menjadi 89,47 kriteria nilai sangat baik pada siklus kedua

Sebagai kontribusi pemikiran untuk keberhasilan pelaksanaan penelitian maka perkenankan peneliti menyampaikan beberapa saran yang diajukan sebagai hasil penelitian ini diantaranya sebagai berikut :

1. Guru

Hendaknya guru membuat dan mengembangankan silabus dan RPP secara rutin, Apabila ada masalah atau kesulitan segeralah minta bantuan kepada teman guru, kepala sekolah, atau pengawas, Kemampuan guru membuat dan mengembangankan silabus dan RPP akan terwujud bila guru ada kemauan untuk aktif dan kreatif.

2. Kepala Sekolah

Pelaksanaan kegaitan pembinaan agar dilaksanakan secara terprogram dan kontinyu, yaitu dengan cara : (a) menyusun program dan perangkat pembinaan, mensosialisasikan program, melaksanakan pembinaan, menindak lanjuti hasil pembinaan. (b) melakukan hubungan dan komunikasi bersifat terbuka dan kekeluargaan antara kepala sekolah dengan guru dan warga sekolah, dan (c) meningkatkan kompetensi, keterampilan dan menambah wawasan kependidikan, ilmu pengetahuan dan teknologi bagi dirinya, guru dan tenaga kependidikan lainnya di sekolah.

\section{DAFTAR RUJUKAN}

Bafadal, I. 2006. Peningkatan Profesionalisme Guru Sekolah Dasar. Jakarta: Bumi Aksara.

Departemen Pendidikan dan Kebudayaan, 1995. Pedoman Pembinaan Profesional Sekolah Dasar. Dikdasmen: Jakarta

Departemen Pendidikan Nasional, 2008. Petunjuk TeknisPenelitian Tindakan Sekolah. Dirjen PMTK: Jakarta.

Depdiknas. 2006. Permendiknas Nomor 22 tahun 2006 tentang Standar Isi untuk Satuan Pendidikan Dasar dan Menengah. Jakarta: Depdiknas.

Depdiknas. 2005. Kamus Besar Bahasa Indonesia Edisi Ke 3. Jakarta: Balai Pustaka.

Gentry, C. G. 1994. Introduction to instructional development: Process and technique. Belmont, CA: Wadsworth Publishing Company.

Jauhari. 2019. Penerapan Metode Pembelajaran Kooperatif Tipe Number Head Together (NHT) Pada Siswa Kelas XI IPS 2 SMA Negeri 2 Watampone Untuk Meningkatkan Hasil Belajar Bahasa Indonesia. JIKAP PGSD, 3 (1): 25-34.

Lundgren, Linda. 1994. Cooperative Learning in The Science Classroom. New York: Gleoncoe Maemillan Mc Graw Hill.

Majid, Abdul. 2005. Perencanaan pembelajaran: Mengembangkan standar Kompetensi Guru. Bandung: Remaja Rosdakarya.

Muhaimin. 2004. Paradigma Pendidikan Islam. Bandung: Remaja Rosdakarya

Mulyasa, E., 2003. Kurikulum Berbasis Kompetensi: Konsep, Karakteristik, dan Implementasi. Bandung: Remaja Rosdakarya

Muslich, Mansur. 2007, Pembelajaran Berbasis Kompetensi dan Kontektual. Jakarta: Bumi Aksara

Reigeluth, C. M. 1983. Instructional Desing theories and models: An overview of their current status. Lawrence Erlbaum Associates, Hillsdale.

Robbins, S. P. 2001. Organizational Behavior, New Jersey: Pearson Education International. 
Salma, Dewi, 2008. Prinsip Disain Pembelajaran (Instructional Design rinciples). Jakarta: Universitas Negeri Jakarta:

Sofo. Francesco. 1999. Human Resource Development, Perspective, Roles and Practice Choice.Business and Professional Publishing, Warriewood, NWS

Spencer, et al. 1993. Competence at Work: Models for Superior

Sumantri, Mulyani. 1988. Kurikulum dan Pengajaran. Jakarta: Departemen Pendididkan dan Kebudayaan.

Suparman, M. A. 1997. Disain Instruksional. Jakarta: PAU PPAI Universitas Terbuka.

Syah, Muhibbin. 2000. Psikologi Pendidikan dengan Pendekatan Baru. Bandung: Remaja Rosdakarya

Thompson, et al. 1991. Personal Computing: Toward a Conceptual Model of Utilization. Mis Quarterly, pp.125-143.

Usman, M. U. 1994. Menjadi Guru Profesional. Bandung: Remaja Rosdakarya.

Yuwono, Ipung. 2001. RME (Realistic Mathematic Education) dan Hasil Studi Awal Implementasinya di SLTP. Makalah disampaikan pada seminar Nasional RME 